\title{
THE BARRIER BETWEEN IRRESPONSIBILITY AND RESPONSIBILITY. CONSIDERATIONS REGARDING THE FORENSIC PSYCHIATRIC EXPERTISEIN CRIMINAL LAW
}

\author{
Marcela SOMICU (BANU) \\ $\mathrm{PhD}$ student, Free International University of Moldova, \\ Chisinau, Republic of Moldova \\ e-mail:marcela.banu@energie.gov.ro \\ https//orcid.org/ 0000-0002-9675-8953
}

\begin{abstract}
The irresponsibility from a medico-legal point of view is supported by the following criteria: nonformation of critical discernment; severe psycho-sensory or mental disability; altering the levels of elementary consciousness and operational logic; the psychopathological motivation of the moment of committing the antisocial act and of the deviant behavior in general; there is a direct causal link between the pathological personality traits and the crime committed; the forensic onset of mental illness; mental incapacity Analyzing all the above and referring to the topic studied in this paper, we can not fail to refer to how it contributes to the mental illness of a person who has committed a crime on determining his state of responsibility or irresponsibility, because this state determines whether or not the person is liable to criminal liability and, respectively, the punishment to be applied. In order to determine whether a person acted with discernment, ie he realized the degree of social danger posed by the act committed and was able to distinguish between what is permitted and what is not permitted by law, it is necessary the conclusions of some specialists.
\end{abstract}

Keywords: forensic expertise, psychiatric expertise, responsibility, irresponsibility, mitigating circumstance, psychopathological deviance, psychomoral deviance.

\section{BARIERA ÎNTRE IRESPONSABILITATE ȘI RESPONSABILITATE. CONSIDERAȚII PRIVIND EXPERTIZA MEDICO-LEGALĂ PSIHIATRICĂ ÎN DREPTUL PENAL}

Iresponsabilitatea din punct de vedere medico-legal este susținută de următoarele criterii: neformarea discernământului critic; psiho-senzorial grav sau handicapul mental; alterarea nivelelor de conștiință elementară și operațional logică; motivația psihopatologică a momentului săvârșirii actului antisocial și a comportamentului deviant în general; existența unei legături directe de cauzalitate între trăsăturile patologice ale personalității și infracțiunea comisă; debutul medico-legal al bolii psihice; incapacitatea psihică. Analizând toate cele spuse mai sus și raportând la tema studiată în prezentul articol nu putem să nu facem referire la faptul cum contribuie afecțiunea psihică pe care o are o persoană care a săvârșit o infracțiune asupra determinării stării sale de responsabilitate sau iresponsabilitate, fiindcă anume această stare determină dacă persoana respectivă este pasibilă sau nu de răspundere penală și, respectiv, pedeapsa care îi va fi aplicată. Pentru a stabili dacă o persoană a acționat cu discernământ, adică și-a dat seama de gradul de pericol social pe care îl prezintă fapta săvârșită și a putut să facă deosebire între aceea ce este permis și ceea ce nu este permis de lege, sunt necesare concluziile unor medici specialiști.

Cuvinte-cheie: expertiză medico-legală, expertiză psihiatrică, responsabilitate, iresponsabilitate, circumstanță atenuantă, devianță psihopatologică, devianță psihomorală.

\section{LA BARRIÈRE ENTRE IRRESPONSABILITÉ ET RESPONSABILITÉ. CONSIDÉRATIONS SUR L'EXPERTISE MÉDICO-LÉGALE PSYCHIATRIQUE EN DROIT PÉNAL}

L'irresponsabilité d'un point de vue médico-légal s'appuie sur les critères suivants: non-formation du discernement critique; handicap psycho-sensoriel ou mental grave; modifier les niveaux de consci- 
ence élémentaire et de logique opérationnelle; la motivation psychopathologique du moment de commettre l'acte antisocial et du comportement déviant en général; il existe un lien de causalité direct entre les traits de personnalité pathologiques et le crime commis; l'apparition médico-légale de la maladie mentale; incapacité mentale En analysant tout ce qui précède et en se référant au sujet étudié dans cet article, on ne peut manquer de se référer à la façon dont il contribue à la maladie mentale d'une personne qui a commis un crime pour déterminer son état de responsabilité ou d'irresponsabilité, car cet état détermine si la personne est passible ou non d'une responsabilité pénale et, respectivement, de la peine à appliquer. Afin de déterminer si une personne a agi avec discernement, c'est-à-dire qu'elle a réalisé le degré de danger social posé par l'acte commis et a pu distinguer ce qui est permis et ce qui n'est pas permis par la loi, il faut les conclusions de certains médecins spécialistes.

Mots-clés: expertise médico-légale, expertise psychiatrique, responsabilité, irresponsabilité, circonstance atténuante, déviance psychopathologique, déviance psychomorale.

\section{БАРЬЕР МЕЖДУ ВМЕНЯЕМОСТЬЮ И НЕВМЕНЯЕМОСТЬЮ. РАЗМЫШЛЕНИЯ ОТНОСИТЕЛЬНО ПСИХИАТРИЧЕСКОЙ СУДЕБНО- МЕДИЦИНСКОЙ ЭКСПЕРТИЗЫ В УГОЛОВНОМ ПРАВЕ}

Невменяемость с точки зрения судебно-медицинской экспертизы подтверждается следующими критериями: отсутствие критической проницательности; тяжелая психосенсорная или умственная отсталость; изменение уровней элементарного сознания и операционной логики; психопатологическая мотивация момента совершения антиобщественного деяния и девиантного поведения в иелом; наличие прямой причинно-следственной связи между патологическими особенностями личности и совершенным преступлением; судебно-медицинская экспертиза психических заболеваний; умственная недееспособность. Анализируя все вышеперечисленное и обрашаясь к теме, изучаемой в данной статье, мы не можем не сослаться на то, как это способствует психическому заболеванию человека, совершивщего преступление, чтобы определить его состояние вменяемости или невменяемости, потому что это состояние определяет, подлежит ли или нет лицо уголовной ответственности и наказанию, соответственно. Чтобы определить, действовал ли человек рассудительно, то есть осознавал ли степень общественной опасности, которую представляет совершенное действие, и мог ли различать то, что разрешено, и то, что не разрешено законом, необходимы выводы некоторых врачей-специалистов.

Ключевые слова: судебно-медииинская экспертиза, психиатрическая экспертиза, вменяемость, невменяемость, смягчающие обстоятельства, психопатологическое отклонение, психоморальное отклонение.

\section{Introducere}

Probațiunea medico-legală psihiatrică în decursul evoluției societăţii omenești a cunoscut mari oscilații fiind legată organic de structura socială a epocilor și statelor și implicit de evoluția conceptelor de drept, mărturie fiind o serie de coduri și legi existente cu mult înaintea erei noastre. În Lex Cornelia se menţionează atenuarea sau chiar inexistenţa responsabilităţii în cazurile de tulburări mintale, iar în Lex Aquilla se cerea examinarea de către medic în cazurile de boli simulate.

La noi în țară, în paginile din Cartea Românească de învățătură de la pravilele împărătești ale lui Vasile Lupu (Iași, 1646) și apoi în În- dreptarea Legii sau Pravila cea Mare a lui Matei Basarab (Târgoviște, 1652) se fac referiri la starea psihică a celor examinați: nebunia putând fi statornică, interminentă și simulate, iar beția dacă se dovedea cu martori constituia o circumstanță atenuantă.

Astfel, responsabilitatea poate fi definită drept starea psihologică a persoanei care are capacitatea de a înţelege caracterul prejudiciabil al faptei, precum şi capacitatea de a-şi manifesta voinţa şi a-şi dirija acţiunile.

In art.21 CP responsabilitatea este prevăzută ca semn ce caracterizează persoana fizică în calitate de subiect al infracţiunii, iar în art.22 CP se dă noţiunea de responsabilitate: "responsabilitatea este starea psihologică 
a persoanei care are capacitatea de a inţelege caracterul prejudiciabil al faptei, precum şi capacitatea de a-şi manifesta voinţa şi a-şi dirija acţiunile”.

Potrivit dispozițiilor art. $23 \mathrm{CP}$, iresponsabilitatea constituie o cauză care înlătură caracterul penal al faptei și care prevede în: alin. (1) "nu este pasibilă de răspundere penală persoana care, în timpul săvârșirii unei fapte prejudiciabile, se afla în stare de iresponsabilitate, adică nu putea să-şi dea seama de acţiunile ori inacţiunile sale sau nu putea să le dirijeze din cauza unei boli psihice cronice, a unei tulburări psihice temporare sau a altei stări patologice". Astfel crima nu va avea criminal dacă are mintea înstrăinată de judecată (alienat mintal), ca urmare a intervenției unei afecțiuni sau deviante psihice.

Materiale utilizate şi metode aplicate. La elaborarea prezentei lucrări au fost studiate şi utilizate cadrul normativ internaţional, regional şi naţional ce asigură protecţia juridică a persoanelor cu devianța psihopatologică, devianța psihomorală și aprecierea corectă a barierei între iresponsabilitate şi responsabilitate și cele privind expertiza medico-legală psihiatrică în materie de drept penal. Au fost folosite metodele: logică, comparativă, a analizei şi sintezei, sistemică.

\section{Rezultate obţinute şi discuţii}

Intre obligațiile pe care le au organele judiciare cu privire la cunoașterea persoanei infractorului se numără și acelea care se referă la deficiențele de natură psihică ale celui cercetat, în care sunt incluse atât devianţa psihopatologică, cât și cea psihomorală, justiția penală fiind, deseori, confruntată cu necesitatea distingerii între cele două, fie în domeniul rezolvării problemelor vizând răspunderea penală și a determinării gradului de vinovăție, fie în cel al luării unor măsuri de ocrotire, chiar față de persoane care nu se fac vinovate de săvârșirea unor infracțiuni, dar prezintă pericol social din cauza unor maladii psihice.
Unii autori susțin că dacă o persoană comite o infracțiune în stare de iresponsabilitate, chestiunea tratării ei nu revine criminologiei, ci exclusiv medicinei. Criminologia trebuie să se ocupe de indivizii responsabili din punct de vedere intelectual care comit infracțiuni. Răspunsul la întrebarea "de ce un nebun comite fapte antisociale?" trebuie să încerce să îl dea psihiatria, și nu criminologia.

$\mathrm{Nu}$ suntem de acord cu această afirmație, deoarece bolnavii psihici, care din cauza maladiilor grave de care suferă au lipsă totală de discernământ și datorită stării mintale nu vor putea fi trase la răspundere penală și deci nu pot deveni infractori în sensul penal al termenului, indiferent de cît de gravă ar fi fapta pe care au comis-o, și faptele care le comit au constituit, însă, încă din faza incipientă a criminologiei, o preocupare prioritară pentru specialiști, iar cercetările în acest domeniu sunt mereu de actualitate.

În noul Cod Penal al RM s-a introdus o nouă noțiune și anume cea de responsabilitate redusă. Astfel, art.231 CP RM alin (1) prevede că: "persoana care a săvârșit o infracţiune ca urmare a unei tulburări psihice, constatată prin expertiza medicală efectuată în modul stabilit, din cauza căreia nu-şi putea da seama pe deplin de caracterul şi legalitatea faptelor sale sau nu le putea dirija pe deplin este pasibilă de responsabilitate penală redusă". Prin urmare, art. 76 alin. (1) lit. d) prevede responsabilitatea redusă drept circumstanță atenuantă în cazul săvârșirii unei infracțiuni.

Astfel, intervine necesitatea efectuării expertizei medico-legale psihiatrice, care reprezintă o activitate specifică instituției medicolegale, ce constă în investigarea stării psihice, oferind justiției o probă științifică în stabilirea responsabilității (cu alte cuvinte răspunde la întrebarea dacă persoana respectivă a acționat sau nu cu discernământ).

Pentru a înțelege mai clar această definiție este necesar a face o precizare și asupra noțiunii de discernământ (termen psihiatric), 
care constituie capacitatea unei persoane de a-și da seama de faptele comise și urmările acestora, de a putea distinge între bine și rău, având reprezentarea consecințelor negative ale faptelor antisociale. De fapt, discernământul este o sinteză a personalității și conștiinței în momentul săvârșirii unei acțiuni. Astfel, discernământul devine criteriul medical al responsabilității persoanei și punct principal al expertizei psihiatric-legale, de care depinde stabilirea cu certitudine a laturii subiective a infracțiunii comise de acesta.

Organele de urmărire penală, precum şi instanțele de judecată sunt obligate ca, atunci când au îndoieli cu privire la discernământul, la starea de sănătate mintală a persoanei care a săvârșit o faptă penală, să o supună unei examinări în cadrul expertizei medico-legale psihiatrice. Dacă pentru majoritatea faptelor pedepsite de legea penală, efectuarea expertizei medico-legale psihiatrice este lăsată la aprecierea procurorului sau a instanţei de judecată, pentru unele infracțiuni grave, efectuarea aceste expertize este obligatorie. Astfel, potrivit dispozițiilor art. $143 \mathrm{CPP}$ al RM se dispune expertiza în mod obligatoriu pentru constatarea: alin. (3) stării psihice și fizice a bănuitului, învinuitului, inculpatului - în cazurile în care apar îndoieli cu privire la starea de responsabilitatea sau la capacitatea lor de a-și apăra de sine stătător drepturile și interesele legitime în procesul penal.

Astfel, expertiza medico-legală psihiatrică își are utilitatea în mai multe ramuri ale dreptului, efectuându-se în următoarele situații: în cazul infracțiunii de omor deosebit de grav; când organul de urmărire penală sau instanța de judecată are îndoieli asupra stării psihice a învinuitului / inculpatului; la infractorii minori cu vârsta cuprinsă între 14 și 16 ani; la pruncucidere (examinarea mamei); pentru instituirea măsurilor de siguranță cu caracter medical; pentru ridicarea acestor măsuri de siguranță propuse de o expertiză medico-legală anterioară.
Obiectivele pentru care se recomandă expertiza medico-legală psihiatrică:

- Dacă persoana expertizată prezintă sau nu tulburări psihice şi diagnosticul actual al acestora;

- Excluderea simulării sau disimulării unei afecţiuni psihice;

- Capacitatea psihică actuală şi dacă subiectul poate fi cercetat sau judecat;

- Capacitatea psihică la momentul săvârșirii faptei;

- Aprecierea discernământului faţă de fapta comisă;

- Recomandarea măsurilor de siguranţă cu caracter medical sau a măsurilor educative prevăzute de Codul penal, în funcţie de pronosticul tulburărilor psihice constatate şi aprecierea gradului lor de periculozitate socială.

Expertiza se efectuează după ce făptuitorul a fost internat într-o clinică de specialitate, unde este supus unor examene clinice și de laborator, care oferă specialiștilor elementele necesare stabilirii prezenței sau absenței discernământului, la data la care făptuitorul a comis infracțiunea.

Pentru a înțelege mai bine ce reprezintă expertiza medico-legală psihiatrică, trebuie sa facem câteva precizări despre modul de desfăşurare a acesteia.

$\mathrm{O}$ expertiză medico-legală psihiatrică nu poate fi redusă la formularea sau enunţarea unui diagnostic, ci presupune o finalitate social-juridică, ce îi conferă valoarea sa probatorie, concludenţa sa.

Plecând de la prevederile legislaţiei actuale şi de la necesităţile practicii juridice şi de asistenţă medico-legală, obiectivele expertizei medico-legale psihiatrice sunt constituite de următoarele:

a) precizarea stării de sănătate (normalitate) psihică a unei persoane;

b) caracterizarea complexă a personalității individului expertizat cu specificarea trăsăturilor acesteia atât în legătură cu diagnosticul 
psihiatric, cât şi din punct de vedere socio-psihologic;

c) stabilirea legăturii de cauzalitate între trăsăturile acestei personalităţi şi elementele constitutive ale actului infracţional sau antisocial săvârșit.

Examenul neuropsihiatric care se efectuează în situaţia când infractorul a fost descoperit imediat după comiterea faptei, reprezintă prima etapă a expertizei psihiatrice. Aceasta se efectuează de o comisie alcătuită din medic legist şi doi medici psihiatri.

Astfel, conform dispozițiilor Regulamentului de activitate a spitalului de psihiatrie, în art. 31 se spune că: ,,condiţie obligatorie pentru spitalizarea persoanelor in spitalul de psihiatrie pentru examinare şi tratament este exprimarea liberului consimţământ sau cererea pacientului" (vezi anexa nr.1). Spitalizarea în staţionarul de psihiatrie (secţie) se efectuează numai de medicul psihiatru. Dacă persoana ce trebuie spitalizată nu a atins vârsta de 18 ani sau conform stării psihice nu este capabilă să-şi expună liberul consimţământ, acceptul pentru internare poate fi primit de la reprezentantul legal, reprezentantul personal sau de instanţa de judecată după caz. În aceeași ordine de idei putem menționa faptul că art. 30 prevede: ,spitalizarea în spitalul de psihiatrie a persoanelor îndreptate la expertiza psihiatrică legală staţionară şi pentru aplicarea măsurilor coercitive cu caracter medical se efectuează doar prin decizia instanțelor de judecată”.

Acest examen trebuie să fie cât mai complet şi mai amănunțit. Rezultatul unui astfel de examen devine mai mult decât necesar, deoarece oferă organului de cercetare ori procurorului, datele necesare care să-i permită a lua hotărârea dacă va continua cercetările faţă de învinuit/inculpat sau este necesar ca acesta să fie mai întâi internat într-un spital de profil.

Raportul de expertiză medico-legală psihiatrică trebuie sa aibă urmatoarele părți componente:
1. obiectivele expertizei în caz concret;

2. documentele consultate (ordonanța, dosarul cauzei, ancheta socială, formularul privind internarea curentă sau examene de specialitate în ambulatoriu, formularul din internări);

3. fapta comisă (tipul faptei, motivele, mobilul, împrejurările în care a fost comisă, modul de săvârșire, comportamentul postfaptic); circumstanțele biologice, cele psihologice;

4. antecedente personale (școlarizare, profesie, situația militară), antecedente patologice, antecedente comportamentale, antecedente penale;

5. mediul social;

6. expertiza medico-legală propriu-zisă (examenul psihic, examenul psihologic, investigații paraclinice special, referitor la faptă - o recunoaște sau nu, sentimental de vinovăție, discuția cazului - excepțional, concluziile).

Acest tip de expertiză face parte din categoria expertizelor individuale, prevăzută în art. 154 din Legea cu privire la expertiza judiciară, constatările etnico-științifice și medico-legale, care stipulează: ,, expertiza individuală se consideră cercetarea pe un caz concret, care se efectuează de către un expert şi se finalizează cu întocmirea unui raport în care sunt formulate concluziile expertului".

Expertiza psihiatrică a infractorilor cu deficiente psihice: oligofreni, idioți, imbecili, cretini etc., nu ridică probleme deosebite dacă există o suficientă documentație, acestea fiind depistate și diagnosticate de timpuriu (grădinițe, școli, armată). O problemă mai deosebită o pun acei cu forme mult mai ușoare, în special cazurile limită, o parte fiind și recuperabile prin dirijarea către instituții specializate.

În dependență de rezultatul raportului de expertiză medico-legală psihiatrică se vor aplica sau nu măsurile de constrângere cu caracter medical, care potrivit art. 99 pot fi, fie internarea într-o instituție psihiatrică cu supraveghere obișnuită, fie internarea într-o instituție medicală cu supraveghere riguroasă. În acest sens, 
art. 13 alin. (1) din Legea privind asistența psihiatrică din 16.12.1997 prevede: ,persoanei suferinde de tulburări psihice care a săvârșit acțiuni periculoase pentru societate se aplică măsuri medicale coercitive în baza hotărârii judecătorești, potrivit temeiurilor și în modul stabilit de Codul penal si Codul de procedură penală”. Pentru ca hotărârea de judecată sa fie completă în privința aplicării acestor măsuri de constrângere, judecătorul trebuie să țină cont de prevederile art.22 din Hotărârea Plenului Curții Supreme de Justiție a RM cu privire la respectarea normelor de procedură penală la adoptarea sentinței care prevede: ,pentru adoptarea sentinței în privința persoanei care a săvârșit o faptă social-periculoasă în stare de iresponsabilitate sau care a avut dereglări psihice după săvârșirea infracțiunii, care îl lipsește de posibilitatea de a-și da seama și a-și controla acțiunile sale, în ședința judiciară trebuie să fie stabilit incontestabil că fapta social-periculoasă, prevăzută de partea specială a C.P., a fost săvârșită de persoana în cauză. Instanța judecătorească trebuie să aprecieze

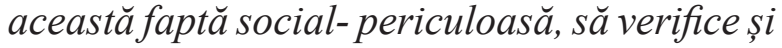
să aprecieze probele prezentate la cercetarea chestiunii privind capacitatea mintală a acestei persoane, caracterul și gradul tulburărilor psihice la momentul săvârșirii infracțiunii și in timpul examinării cauzei în judecată. Dacă instanța de judecată va ajunge la concluzia că anume această persoană a săvârșit fapta social - prevăzută de legea penală în stare de iresponsabilitate, ea urmează să soluționeze chestiunea privind aplicarea unei măsuri de constrângere cu caracter medical".

Aceste măsuri de siguranță se aplică persoanelor care au săvârșit infracțiuni și sunt bolnave ori anormale din punct de vedere psihic:

a) obligația la tratament medical privește persoanele care au săvârșit infracțiuni sub imperiul unei boli ori a unei intoxicări cornice prin alcool sau stupefiante și care prezintă pericol social de a comite noi infracțiuni. Obli- garea la tratament medical durează până la însănătoșire, condamnatul este obligat să efectueze tratamentul, iar dacă se sustrage, această măsură se înlocuiește cu internarea medicală, care înseamnă privare de libertate.

b) o măsură deosebită de siguranță este internarea medicală, caz în care, în aceleași condiții (săvârșirea unei crime, pericol social), făptuitorul este o persoană bolnavă mintal sau toxicoman, care nu răspunde penal și căreia i se aplică internarea într-o instituție sanitară de specialitate, unde va sta până la însănătoșire.

\section{Concluzii}

Din punct de vedere medico-legal iresponsabilitatea este susținută de următoarele criterii: neformarea discernământului critic; handicapul mental sau psiho-senzorial grav; alterarea nivelelor de conștiință elementară și operațional logică; motivaţia psihopatologică a momentului săvârșirii actului antisocial și a comportamentului deviant în general; existent unei legături directe de cauzalitate între trăsăturile patologice ale personalității și infracțiunea comisă; debutul medico-legal al bolii psihice; incapacitatea psihică.

Deși deficiențele de natură psihică sunt de domeniul specific al psihiatriei, în studierea lor este interesată și criminologia, deoarece aceste deficiențe gravitează în jurul licitului sau al ilicitului penal. Împărtășim această parere, deoarece este bine cunoscut deja că deficiențele psihice influențează într-o mare măsură personalitatea infractorului şi chiar dacă acesta este iresponsabil și nepasibil de pedeapsă penală, totuși, constituie un pericol pentru societate.

\section{Bibliografie}

1. BELIȘ, V., Medicină legală. Curs pentru facultățile de științe juridice, Casa editorială Odeon, București, 1999, pag. 161.

2. BOGDAN, S., Criminologie, Sfera juridică, 2005, pag.41. 
3. Codul Penal al Republicii Moldova, din 18.04.2002, pulicat în Monitorul Oficial nr.72-74 al RM la 14.04.2009.

4. Codul Penal al RM, din 13.09.2002, cu modificări - Monitorul Oficial nr.72-74, din 14.04.2009.

5. Cod de Procedură Penală a RM, din 14.03.2003,publicat in Monitorul Oficial nr.104110,la 07.06.2003, în vigoare din 12.06.2003.

6. CIOCLEI, V., Cercetarea criminologică, Editura All Beck, Timișoara, 1998, pag. 15.

7. DRUGESCU, N., Medicină legală., Curs pentru student, Editura Printech, 2001, pag. 133.

8. Hotărârea Plenului Curții Supreme de Justiție a RM cu privire la respectarea normelor de procedură penală la adoptarea sentinței nr.10 din 24.04.2000.

9. IACOBUȚĂ, I.A., Criminilogie, Editura Junimea, Iași, 2002, pag 186.

10. Legea cu privire la asistența psihiatrică din 16.12.1997, publicată în MO 44-46 la 21.05.1998.

11. Legea cu privire la expertiza judiciară , constatările ethnico-științifice și medico-legale din 23.06.2000, publicată în Monitorul Oficial nr.144145 , la 16.11.2000.
12. OANCEA, I., Probleme de criminologie, Editura all Educational, 1998, pag. 195.

13. Regulamentul de activitate a spitalului de psihiatrie, Anexa nr.3 la Ordinul Ministeruluii Sănătăţii nr.591, din 20.08.2010.

14. TĂNĂSESCU, I., TĂNĂSESCU, G., TĂNĂSESCU. C., Tipologii criminogene, Editura C.H.Beck, 2007, pag. 3.

15. UNGUREANU, A., Prelegeri de criminologie, Editura Cugetarea Iași, 1999, pag. 202.

16. http://legearm.com/codul-penal-al-rm-partea-generala/articolul-22-responsabilitatea.html

17. http://ru.scribd.com/doc/23708012/Expertiza-Medico-legala-Psihiatrica

18. http://www.rasfoiesc.com/educatie/psihologie/Scopul-expertizei-medicolegale79.php

19. http://www.umfiasi.ro/Rezidenti/suporturidecurs/Facultatea\%20de\%20Medicina/Medicina\%20 Legala\%20-\%20modul\%20Medicina\%20Legala/ Expertiza\%20medico-legala\%20psihiatrica.pdf

20. http://www.referat.ro/referate/Expertiza_medico-legala_psihiatrica_c3538.html

21. http://www.referat.ro/referate/Expertiza_medico-legala_psihiatrica_c3538.html 